\title{
A cross-country comparative study of entrepreneurship ecosystem using the metafrontier Malmquist method
}

\author{
Ali Naghi Mosleh Shirazia and Sahar Mohamadi ${ }^{\text {** }}$
}

${ }^{a}$ Professor, Department of Management, Shiraz University, Shiraz, Iran

${ }^{b}$ Department of Management, Shiraz University, Shiraz, Iran

CHRON I C L E A B T T A C T

Article history:

Received: November 26, 2017

Received in revised format: January 31,2018

Accepted: April 17, 2018

Available online:

April 17, 2018

Keywords:

Entrepreneurship

Entrepreneurship Ecosystem

Metafrontier Malmquist
Evaluation of the national entrepreneurship ecosystem is one of the most important measures that most countries are committed to. This study evaluates the entrepreneurship ecosystem of the countries in accordance with the Global Entrepreneurship index (GEI) and based on the metafrontier Malmquist approach. The metafrontier Malmquist method helps to find the pattern of change for each country, to perform analyses dynamically, to identify the effects of technical and technology changes among the total changes (Malmquist), and to consider the region and level of the countries in analyses (metafrontier). The data Global Entrepreneurship index for 132 countries from 2016 to 2017 are derived from the reports of the Global Entrepreneurship and Development Institute. Results show that the productivity of the entrepreneurship ecosystem generally increased, but the deeper analysis indicates that this improvement was due to the technology improvement, not the technical efficiency improvement. Meanwhile, the North America region has had the best technical performance in the development of entrepreneurship ecosystem, and other areas, especially Latin America, and The Caribbean and South Asia have experienced a decline in technical efficiency. It was also found that East Asia, and Pacific, Middle East and North Africa and North America maintained a technology gap in the area of entrepreneurship ecosystems, and Latin America and The Caribbean and South Asia regions had the potential to develop technological standards. By analyzing the metafrontier, simple analysis of the entrepreneurship ecosystem performance was replaced with the deep analysis, and a more comprehensive view was achieved in this area.

\section{Introduction}

Since early definitions of entrepreneurship emphasized on the individual role and the entrepreneurship was seen as a kind of individual attitude and behavior, the primary (initial) efforts of most governments to develop entrepreneurship were also limited to the individual-level policies. It was assumed that the entrepreneurship would be quantitatively and qualitatively developed by educating people, creating culture, and forming an appropriate image for entrepreneurs in society. However, experience has shown that the existence of the entrepreneurial spirit and motivation in people is not enough, but the emergence of entrepreneurship requires a desirable environment. Since the entrepreneurship heavily depends on the background in which the entrepreneur is active (including community, institutional environment 
and physical environment), the use of the term "entrepreneurship ecosystem" has expanded in the literature of entrepreneurship policy-making. At present, researchers of the entrepreneurship policy-making area have reached a consensus that countries do not need a large number of entrepreneurs (meaning new or self-employed businesses), but they need to have good and qualitative entrepreneurship ecosystems to achieve economic growth and development (Davari et al., 2017).

The concept of the business ecosystem was first introduced by Moore (1993). His goal was to explain the economic communities and to build innovative value through a new view. According to Moore (1996), actors in ecosystem are firms or companies that are directly involved in the creation of common values and are stakeholders, governments, and legislators. Studies show that the entrepreneurial ecosystems have rapidly become a common tool in the study of entrepreneurship geography. Ecosystems are a set of centralized cultural perspectives, social networks, financial support, universities and active economic policies, which create supportive environments for innovation-based hazardous business (Spigel, 2017). Although recent interest of academic researchers in entrepreneurship ecosystems is due to its popularity among policy makers and entrepreneurs, this interest is a part of a larger process (trend) in entrepreneurship studies. The basic ideas of entrepreneurship ecosystems emerged for the first time in 1980s and 1990s as a part of shift in entrepreneurship studies from individualist and character-based study to a broader perspective, including the role of social, cultural and economic forces in the entrepreneurial process (Drakopoulou Dodd \& Anderson, 2007). In particular, the position of entrepreneurship has a significant impact on the entire entrepreneurial process, from the ability and desire of the emerging entrepreneur for establishing a company to the ability to obtain capital and eventually to leave the firm. Pennings (1982), Dubini (1989), Van de Ven (1993), Bahrami and Evans's work (1995) introduced the concept of entrepreneurial environments or ecosystems to explain the impact of economic and social factors on the entrepreneurial process. Based on previous movements that consider entrepreneur as the only source of value creation, this conceptual shift emphasizes the importance of considering the entrepreneurship phenomenon in a broader extent, including, temporal, spatial, social, organizational, and market dimensions (Zahra et al., 2014). During the past decade, while entrepreneurship researchers were sensitive towards different areas such as location, the impact of background (context) has often been underestimated or controlled (Walter, 2011; Walter \& Dohse, 2012). It means that the previous studies in association with entrepreneurship were attempting to eliminate the role of the background (context) in order to obtain generic models of entrepreneurial activity, while the background (context) should be the special concentration of research. A background (context) such as location (place) should not be observed as a control variable or simple proxy. A better examination of the relationship between the effect of structures, and cultural, social, political, and economic processes of a place on all characteristics of the entrepreneurial path is necessary. Background (context) like location is not a necessary cause for a specific entrepreneurial technique, but represent a more complex effect on entrepreneurship (Johannisson, 2011). Evaluation of the entrepreneurship ecosystem at national level is considered as one of the prominent measures that most developed or developing countries are looking for. There are various techniques and firms for evaluating the entrepreneurship ecosystems, which would be addressed in theoretical fundamentals in more details. Therefore, in developed countries, evaluating the entrepreneurship ecosystem is necessary for being progressive, and in developing countries this evaluation is essential for estimating their position and accelerating the rate of progress in the area of entrepreneurship. Hence, the performance of various countries should be evaluated using the entrepreneurship ecosystem criteria (Gnyawali \& Fogel, 1994). Previous analyses have merely examined the criteria individually, and only focused on the output. The issue that which resources and possibilities were implemented by the countries to reach the output, have not been considered, and the change pattern for each country is not clear. The solution to this limitation is to use the data envelopment technique. Another limitation of the previous studies is merely cross-sectional analysis. This means that analyses are made only by taking pictures of a given time period, and processes (trends) was not considered, as well as in the performance analysis, performance of the countries was not distinguished from the growth of technology. To overcome these limitations, Malmquist method is used. Finally, the last limitation is that the region and the level of the countries have not been considered to 
analyze the entrepreneurship ecosystem. The solution applied for eliminating this limitation is the use of metafrontier Malmquist method. The metafrontier approach makes it possible to assess a unit in the light of the technology, specific level of the group, and also cross-border of that unit. Hence, the present study is aimed to evaluate the entrepreneurial ecosystem of the classified countries (regionally), at the World Bank, in accordance with the Global Entrepreneurship Indices (GEI) and based on the metafrontier Malmquist method.

\section{Literature review}

The literature on the entrepreneurship development is categorized into three sections: study on the impact of individual factors on entrepreneurship success and performance; study on the impact of environmental factors on entrepreneurship success and performance, and the study on the impact of individual and environmental factors on entrepreneurship success and performance. The issue of Entrepreneurship Ecosystem falls into the third category of studies (Entezari, 2015). The concept of entrepreneurship ecosystem has become popular in recent years, due to business books such as Feld's Startup Communities (2012) and work by Isenberg (2010) in Harvard Business Review. These works led to the popularity of the idea related to the considerable effect of the community and culture on the entrepreneurial process of that place among entrepreneurial leaders and policy-makers. Despite its popularity, concept of entrepreneurial ecosystem, does not have a broadly common definition among scholars and researchers. The first component of this term is entrepreneurship: the process in which the opportunities for creating new goods and services are investigated, evaluated and implemented (Shane \& Venkataraman, 2000). Entrepreneurship ecosystem is a rapidly growing or scalable start-up and this kind of entrepreneurship is an essential part of innovation, productivity growth and employment (Mason \& Brown, 2014). Empirically, this claim is excessively exclusive: Innovation startup networks or entrepreneurial employees is a type of productive entrepreneurship (Baumol, 1996). However, it is obvious that the entrepreneurship ecosystem approach does not, in its definition, describe the traditional statistical entrepreneurship indices, such as self-employment or small business, to the entrepreneurship. This distinction between the traditional criteria of entrepreneurship and more appropriate conceptual criteria of entrepreneurship, such as innovative growth-oriented entrepreneurship, has been highly emphasized in entrepreneurship literature (Henrekson \& Sanandaji, 2014).

The second component of the term is ecosystem. The biological interpretation of this concept, in which the interaction of living organisms with their physical environment is centrally located, should not be clearly considered in the true sense of the word. Instead, the entrepreneurial ecosystem approach emphasizes that the entrepreneurship appears in a society of interdependent actors (Freeman \& Audia, 2006). More specifically, the literature associated with the entrepreneurship ecosystems concentrates on the context role (social) in enabling or restricting the centralized entrepreneurship, and therefore, has a relationship with other recent entrepreneurship systems or systematic entrepreneurship research methods (Sternberg, 2007; Ács et al., 2014 ) that often attempt to build entrepreneurship studies to the innovation system approach. Unlike the previous application of the ecosystem term in the management literature, such as Moore (1993) and Iansiti \& Levien (2004) which concentrated on organizing an industry or centralized value chain, the entrepreneurship ecosystems have inherently geographic perspective. Researchers expressed a variety of viewpoints on the Entrepreneurship Ecosystem, which also have some similarities including the unique nature of each ecosystem and its existence in a specific geographic region. Cohen (2006) explained the ecosystem as follows: "An entrepreneurial ecosystem represents a different set of interdependent activists in a geographic region that is affected by the combination of all group activists and regional economic potential. Ecosystems are a set of interdependent components that interact with each other and seek to create risky (hazardous) business over the time. Cohen defined the ecosystem as a group of interdependent activists in a local geographic region that is committed to sustainable development by supporting and facilitating sustainable hazardous (risky) businesses". Quoted by Cohen (2006), Van De Van (1993) believes that "the entrepreneurial ecosystem is gradually evolving over the time through a set of interdependent indicators that interact with each other to create new risky (hazardous) business. Entrepreneurship ecosystem is based on innovation 
support, and organizes and coordinates a diverse range of actors". According to Feldman et al. (2005), at the core of an entrepreneurial ecosystem, at least one or more large businesses have been established, carrying out the research, development, and production activities, and playing an essential role in the development of ecosystems. They hire a skillful workforce and provide their employees with the conditions to reach higher levels of business and education, and actually, are sources of new businesses (Adams, 2011). According to Feld's viewpoints, in contrast to other economic approaches, ecosystems do not consider entrepreneurship as the result of the system, but emphasizes on the entrepreneur and his/her importance in keeping the ecosystems. In his viewpoint, the entrepreneurs are the main heart of a successful entrepreneurship ecosystem, and successful ecosystems have specific characteristics. After key role of Entrepreneurs (in leading the development of the ecosystem as well as the role of the mentor or advisor), in 2012, Feld emphasizes the interaction between actors of the ecosystem (with a very large network, the number of related events and the collaboration of large companies with local startups) and evaluating the relevant kinds of sources (intelligence, services, capital) by activating the role of government in background.

Quoted by Amolo and Migiro (2015), Simrie et al. (2011) define entrepreneurship ecosystems as facilities, resources, people, and the entrepreneurial environment which are considered essential for realizing the entrepreneurship. In general, entrepreneurship ecosystems appear in places with specific characteristics. From Isenberg's point of view (2011), "entrepreneurship ecosystem has four characteristics: 1. Ecosystem consists of 6 dimensions (policy, financing, culture, support, human capital, markets). 2. Each entrepreneurship ecosystem is unique. For example, Silicon Valley is not repeatable. 3. Identifying the root reasons of the success in an entrepreneurship ecosystem is impossible due to multidimensional and cause and effect relationships. 4. Efficiency of an entrepreneurship ecosystem depends on strengthening all aspects of the six dimensions". The Entrepreneurship Ecosystem Strategy is a new and cost-effective strategy for the development of entrepreneurship and, ultimately, economic progress. In his opinion, this strategy is at least a complementary or even pre-requisite of cluster strategies, innovation systems, knowledge-based economies, and national competitiveness policies. Spiegel (2015) considered features of an ecosystem in three parts with distinct cultural (supportive culture, background for entrepreneurs), social (networks, employee talent, investment force, mentors and role patterns), and material (politics, universities, infrastructures, free markets and supportive systems) features. These sub-characteristics are unique for each ecosystem compared to another ecosystem. These characteristics create benefits and resources for entrepreneurs, and the relationships between these characteristics keep the ecosystem alive and can reproduce it. Ács and Szerb (2010) introduced a new index called "Entrepreneurship Development Index", based on three phases or sub-indices (entrepreneurial orientation and perception, entrepreneurial activity, and entrepreneurial enthusiasm), and considered the individuals, firms and organizational levels together and step in creating the new entrepreneurship indices. Therefore, the importance of the global entrepreneurship index is to consider the organizations related to the entrepreneurship individual-firm level. Selecting a combination of indices from various international organizations leads to strengthening the systemic thinking. Global Entrepreneurship Development Institute (GEDI) is an authoritative research organization that studies on association between entrepreneurship, economic development and prosperity (welfare). The institute is located in Washington, DC. The main project of the institute is the Global Entrepreneurship Index (GEI), an extraordinary improvement in the assessment of the quality and dynamism of entrepreneurship ecosystems at the national and regional levels. (Global Entrepreneurship Index, 2017). Table 1 presents components of the Global Entrepreneurship Index. While the work on entrepreneurship ecosystems is still in its infancy stages, several empirical researches state that a rich entrepreneurship ecosystem has the capability of entrepreneurship and generating value at the regional level (Fritsch, 2013). For instance, Mack and Mayer (2016) investigated how the strong entrepreneurship culture, public supportive policies, entrepreneurship trends in Phoenix, Arizona, helped to build a strong entrepreneurship ecosystem. Studies on other areas, including Silicon Valley (Patton \& Kenney, 2005), Washington DC (Feldman, 2001) and Kyoto (Aoyama, 2009) - even if they did not specifically use the term "entrepreneurship ecosystem", described that the combination of location-based elements created throughout the history could 
provide the conditions for long-term success of entrepreneurship. The work of several researchers such as Ács et al. (2014) to identify the strong entrepreneurship ecosystems and to illustrate the various local factors associated with high levels of innovative entrepreneurship include large-scale quantitative methods.

\section{Table 1}

Elements of Global Entrepreneurship Index

\begin{tabular}{lll} 
& \multicolumn{1}{c}{ Sub index } & \multicolumn{1}{c}{ Pillars } \\
\cline { 2 - 3 } & & Opportunity perception \\
& Entrepreneurial Attitudes & Startup skills \\
& & Risk Acceptance \\
& Networking \\
\cline { 2 - 3 } Global Entrepreneurship Index & Cultural Support \\
\cline { 2 - 3 } & Entrepreneurial Abilities & Opportunity startup \\
& Technology Absorption \\
\cline { 2 - 3 } & Human capital \\
\hline \multirow{3}{*}{ Entrepreneurial Aspiration } & Competition \\
\hline & Product Innovation \\
& Process Innovation \\
& High Growth \\
& Internationalization \\
& Risk Capital \\
\hline
\end{tabular}

\section{Methodology}

\subsection{Research method}

In terms of purpose, the present study is an applied research and data collection type is descriptive and quantitative. For collecting data, reports of the Global Entrepreneurship index published by the Global Entrepreneurship and Development Institute have been used. Statistical population of this study includes 132 countries, which have been categorized in 7 regions based on the information of Global Bank, and their data used in 2016 and 2017. Data analysis method is a metafrontier Malmquist, next sections explain why it is used. The Malmquist Productivity index has been used in many programs to compare the productivity growth of different units. This direct comparison assumes that units have similar characteristics and they have access to similar technologies. In other words, it is assumed that units are comparable because they have similar production boundaries (Molinos-Senante et al., 2015). Conceptually, when units of a technology set (group) are faced with the same production boundary, the productivity of each unit can be measured by the radial distance function, which is presented as the output ratio to the boundary output level. Meanwhile, since the units are faced with the similar boundary, the productivity of units is comparable (Lu et al., 2015). In all the previous studies, it has been assumed that all standards for the production of units are equal ( $\mathrm{Lu}$ et al., 2015). All decision-making units were considered to have similar technologies. The differences in technology and the available resources that affect the productivity and efficiency of decision-making units were ignored (Lin et al., 2013). There is usually a great heterogeneity among units. Despite the high degree of heterogeneity, most studies have been designed to estimate the productivity or production function with the help of relatively simple models that ignore many heterogeneities (Wolff, 2013).

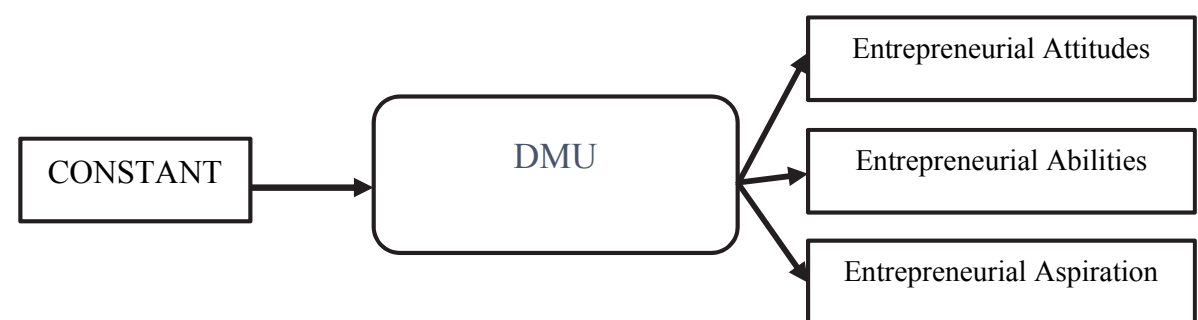

Fig. 1. Pure output-oriented Data Envelopment Analysis model for entrepreneurship ecosystems

The approach used for this limitation is to apply the metafrontier Malmquist. The metafrontier approach makes it possible to assess a unit with regard to the technology, the specific level of the group, as well 
as its metafrontier. In order to form the metafrontier Malmquist, the pure output-oriented Data Envelopment Analysis is used. This model is used for situations, in which the important existing indices are completely considered as the output and the input rate of the units assumes to be constant (Fig. 1).

\subsection{Metafrontier Malmquist}

Metafrontier Malmquist productivity index is the extended form of Malmquist index (Chung \& Heshmati, 2013). Let us assume that production technology can be defined as capability or knowledge transforming inputs into outputs. Under a multi-output and a multi-input context, in period $t$, firms use an input vector $x_{t} \mathrm{CR}^{+\mathrm{M}}$ to produce an output vector $\mathrm{y}_{\mathrm{t}} \in \mathrm{R}^{+\mathrm{L}}$ : We first suppose that there are $K$ technology sets (groups) $S_{\mathrm{k}}$ in an industry, and $k=1,2, \ldots, K$, whereas the technologically feasible input-output combinations can be categorized into the same technology sets:

$$
\mathrm{S}_{\mathrm{t}}^{\mathrm{k}}=\left\{\left(\mathrm{x}_{\mathrm{t}}^{\mathrm{k}}, \mathrm{y}_{\mathrm{t}}^{\mathrm{k}}\right): \mathrm{x}_{\mathrm{t}}^{\mathrm{k}} \text { is optained from } \mathrm{y}_{\mathrm{t}}^{\mathrm{k}}\right\}
$$

The output-oriented output set $P^{K}$ can be expressed as:

$$
\mathrm{p}_{\mathrm{t}}^{\mathrm{k}}\left(\mathrm{x}_{\mathrm{t}}^{\mathrm{k}}\right)=\left\{\mathrm{y}_{\mathrm{t}}^{\mathrm{k}}:\left(\mathrm{x}_{\mathrm{t}}^{\mathrm{k}}, \mathrm{y}_{\mathrm{t}}^{\mathrm{k}}\right) \in \mathrm{s}_{\mathrm{t}}^{\mathrm{k}}\right\}
$$

The upper boundary of the output set is defined as the group frontier of group $k$, which indicates the attainable maximum output level that firms confront, regarding the fact that the technological difference among groups cannot be exceeded. Thus, the output-oriented distance function of this group $k$ is as:

$$
\mathrm{D}_{\mathrm{t}}^{\mathrm{k}}\left(\mathrm{x}_{\mathrm{t}}^{\mathrm{k}}, \mathrm{y}_{\mathrm{t}}^{\mathrm{k}}\right)=\inf \left\{\delta>0:\left(\frac{\mathrm{y}_{\mathrm{t}}^{\mathrm{k}}}{\delta}\right) \in \mathrm{p}_{\mathrm{t}}^{\mathrm{k}}\left(\mathrm{x}_{\mathrm{t}}^{\mathrm{k}}\right)\right\},
$$

Because the distance function refers to the ratio of actual output to the output level on the frontier, according to Farrell (1957), output-oriented technical efficiency can be measured as:

$$
0 \leq \mathrm{TE}_{\mathrm{t}}^{\mathrm{k}}\left(\mathrm{x}_{\mathrm{t}}^{\mathrm{k}}, \mathrm{y}_{\mathrm{t}}^{\mathrm{k}}\right)=\mathrm{D}_{\mathrm{t}}^{\mathrm{k}}\left(\mathrm{x}_{\mathrm{t}}^{\mathrm{k}}, \mathrm{y}_{\mathrm{t}}^{\mathrm{k}}\right) \leq 1
$$

Now, it is assumed that the groups $\mathrm{s}^{\mathrm{k}}$ indeed belong to an unrestricted common technological set $\mathrm{s}^{*}$. This set is defined as:

$$
\begin{aligned}
\mathrm{S}_{\mathrm{t}}^{*} & =\left\{\mathrm{s}_{\mathrm{t}}^{1} U \mathrm{~s}_{\mathrm{t}}^{2} \mathrm{U} \ldots \cup \mathrm{s}_{\mathrm{t}}^{\mathrm{k}}\right\} \\
\mathrm{S}_{\mathrm{t}}^{*} & =\left\{\left(\mathrm{x}_{\mathrm{t}}, \mathrm{y}_{\mathrm{t}}\right): \mathrm{y}_{\mathrm{t}} \text { can generate } \mathrm{x}_{\mathrm{t}}\right\}
\end{aligned}
$$

Then, the output-oriented output set now can be represented as:

$$
\mathrm{P}_{\mathrm{t}}^{*}\left(\mathrm{x}_{\mathrm{t}}\right)=\left\{\mathrm{y}_{\mathrm{t}}:\left(\mathrm{x}_{\mathrm{t}}, \mathrm{y}_{\mathrm{t}}\right) \in \mathrm{s}_{\mathrm{t}}^{*}\right\}
$$

The upper boundary of this output set refers to the 'metafrontier' of firms in all groups. Unlike the group frontiers, the metafrontier is constructed on the basis that all producers in each group have potential access to the same technologies.Thus, the upper boundary now faced by firms is the metafrontier and no longer the group frontiers. The output-oriented distance function is defined as:

$$
\mathrm{D}_{\mathrm{t}}^{*}\left(\mathrm{x}_{\mathrm{t}}, \mathrm{y}_{\mathrm{t}}\right)=\inf \left\{\delta>0:\left(\frac{\mathrm{y}_{\mathrm{t}}}{\delta}\right) \in \mathrm{p}_{\mathrm{t}}^{*}\left(\mathrm{x}_{\mathrm{t}}\right)\right\} \text {. }
$$

Hence, the metafrontier technical efficiency measure can be captured by the distance function and expressed as:

$0 \leq \mathrm{TE}_{\mathrm{t}}^{*}\left(\mathrm{x}_{\mathrm{t}}, \mathrm{y}_{\mathrm{t}}\right)=\mathrm{D}_{\mathrm{t}}^{*}\left(\mathrm{x}_{\mathrm{t}}, \mathrm{y}_{\mathrm{t}}\right) \leq 1$.

Meanwhile, Eq. (5) also implies that the metafrontier is an envelopment curve of the group frontiers, and that the correlation between the technical efficiency measured on the basis of the metafrontier and group frontiers is known as:

$$
\mathrm{D}_{\mathrm{t}}^{*}\left(\mathrm{x}_{\mathrm{t}}, \mathrm{y}_{\mathrm{t}}\right) \leq \mathrm{D}_{\mathrm{t}}^{\mathrm{k}}\left(\mathrm{x}_{\mathrm{t}}, \mathrm{y}_{\mathrm{t}}\right) \Rightarrow \mathrm{TE}_{\mathrm{t}}^{*}\left(\mathrm{x}_{\mathrm{t}}, \mathrm{y}_{\mathrm{t}}\right) \leq \mathrm{TE}_{\mathrm{t}}^{\mathrm{k}}\left(\mathrm{x}_{\mathrm{t}}, \mathrm{y}_{\mathrm{t}}\right) .
$$

The technology gap ratio can also be defined as: 


$$
\begin{aligned}
& 0 \leq \operatorname{TGR}_{t}^{k}\left(x_{t}, y_{t}\right)=\frac{D_{t}^{*}\left(x_{t}, y_{t}\right)}{D_{t}^{k}\left(x_{t}, y_{t}\right)}=\frac{T_{t}^{*}\left(x_{t}, y_{t}\right)}{T_{t}^{k}\left(x_{t}, y_{t}\right)} \leq 1 \\
& \operatorname{TE}_{t}^{*}\left(x_{t}, y_{t}\right)=\operatorname{TE}_{t}^{k}\left(x_{t}, y_{t}\right) \times \operatorname{TGR}_{t}^{k}\left(x_{t}, y_{t}\right)
\end{aligned}
$$

Shifting the focus to the domain measuring productivity index, and referring to Caves et al. (1982a, b), for a firm belonging to group $k$, the cross-period change in productivity (MPI) regarding period $t$ as the base year can be measured as:

$$
\operatorname{MPI}_{\mathrm{t}}^{\mathrm{k}}=\frac{\mathrm{D}_{\mathrm{t}}^{\mathrm{k}}\left(\mathrm{x}_{\mathrm{t}+1}, \mathrm{y}_{\mathrm{t}+1}\right)}{\mathrm{D}_{\mathrm{t}}^{\mathrm{k}}\left(\mathrm{x}_{\mathrm{t}}, \mathrm{y}_{\mathrm{t}}\right)}
$$

Furthermore, the productivity change regarding period $t+1$ as the base year is:

$$
\operatorname{MPI}_{\mathrm{t}+1}^{\mathrm{k}}=\frac{\mathrm{D}_{\mathrm{t}+1}^{\mathrm{k}}\left(\mathrm{x}_{\mathrm{t}+1}, \mathrm{y}_{\mathrm{t}+1}\right)}{\mathrm{D}_{\mathrm{t}+1}^{\mathrm{k}}\left(\mathrm{x}_{\mathrm{t}}, \mathrm{y}_{\mathrm{t}}\right)}
$$

Eq. (14) can then be decomposed into:

$$
\operatorname{MPI}_{t, t+1}^{\mathrm{k}}\left(\mathrm{x}_{\mathrm{t}}, \mathrm{y}_{\mathrm{t}}, \mathrm{x}_{\mathrm{t}+1}, \mathrm{y}_{\mathrm{t}+1}\right)=\frac{\mathrm{D}_{\mathrm{t}+1}^{\mathrm{k}}\left(\mathrm{x}_{\mathrm{t}+1}, \mathrm{y}_{\mathrm{t}+1}\right)}{\mathrm{D}_{\mathrm{t}}^{\mathrm{k}}\left(\mathrm{x}_{\mathrm{t}}, \mathrm{y}_{\mathrm{t}}\right)} \times\left[\frac{\mathrm{D}_{\mathrm{t}}^{\mathrm{k}}\left(\mathrm{x}_{\mathrm{t}+1}, \mathrm{y}_{\mathrm{t}+1}\right)}{\mathrm{D}_{\mathrm{t}+1}^{\mathrm{k}}\left(\mathrm{x}_{\mathrm{t}+1}, \mathrm{y}_{\mathrm{t}+1}\right)} \times \frac{\mathrm{D}_{\mathrm{t}}^{\mathrm{k}}\left(\mathrm{x}_{\mathrm{t}}, \mathrm{y}_{\mathrm{t}}\right)}{\mathrm{D}_{\mathrm{t}+1}^{\mathrm{k}}\left(\mathrm{x}_{\mathrm{t}}, \mathrm{y}_{\mathrm{t}}\right)}\right]^{1 / 2}
$$

In Eq. (16), the first term on the right-hand side represents the technical efficiency change (TEC) and the second term denotes the technical change (TC) as expressed by a geometric mean of the shift in the frontier that is measured by using the points of input-output combinations of periods and $t+1$ as a reference. From Eq. (16), we see that the index is based on the k-th group frontier. O'Donnell et al. (2008) dubbed this the group Malmquist productivity index (GMPI). Thus, the simplified expression of Eq. (15) would be:

$$
\mathrm{GMPI}_{\mathrm{t}, \mathrm{t}+1}=\mathrm{TEC}_{\mathrm{t}, \mathrm{t}+1}^{\mathrm{k}} \times \mathrm{TC}_{\mathrm{t}, \mathrm{t}+1}^{\mathrm{k}}
$$

Furthermore, if the MPI measure is based on the metafrontier, then the MMPI is defined as:

$$
\operatorname{MPI}_{t, t+1}\left(x_{t}, y_{t}, x_{t+1}, y_{t+1}\right)=\left[\frac{D_{t}^{*}\left(x_{t+1}, y_{t+1}\right)}{D_{t}^{*}\left(x_{t}, y_{t}\right)} \times \frac{D_{t+1}^{*}\left(x_{t+1}, y_{t+1}\right)}{D_{t+1}^{*}\left(x_{t}, y_{t}\right)}\right]^{1 / 2}
$$

Eq. (17) can also be decomposed as:

$$
=\frac{D_{t}^{*}\left(x_{t+1}, y_{t+1}\right)}{D_{t}^{*}\left(x_{t}, y_{t}\right)} \times\left[\frac{D_{t}^{*}\left(x_{t+1}, y_{t+1}\right)}{D_{t+1}^{*}\left(x_{t+1}, y_{t+1}\right)} \times \frac{D_{t}^{*}\left(x_{t}, y_{t}\right)}{D_{t+1}^{*}\left(x_{t}, y_{t}\right)}\right]^{1 / 2}
$$

The simplified expression is as follows,

$$
\mathrm{MMPI}_{\mathrm{t}, \mathrm{t}+1}=\mathrm{TEC}_{\mathrm{t}, \mathrm{t}+1}^{*} \times \mathrm{TC}_{\mathrm{t}, \mathrm{t}+1}^{*}
$$

where the TEC represents the TEC measured on the basis of the metafrontier. At a country level, a value larger than unity signifies the movement of a firm's output towards the output level on the metafrontier, thereby referring to the definition of catch-up in Farrell et al. (1957) and technological catchup in Kumbhakar and Wang (2005). Furthermore, rearranging Eq. (18), the term in the technology gap ratio would emerge in the decomposition of the MMPI; O'Donnell (2008) also named it catch-up:

$$
\mathrm{MMPI}_{\mathrm{t}, \mathrm{t}+1}=\mathrm{TEC}_{\mathrm{t}, \mathrm{t}+1}^{\mathrm{k}} \times \mathrm{TC}_{\mathrm{t}, \mathrm{t}+1}^{\mathrm{k}} \times\left[\operatorname{catch}-\mathrm{up}_{\mathrm{t}, \mathrm{t}+1}^{\mathrm{k}}\right]^{-1}
$$

where

$$
\left[\text { catch }-u_{t, t+1}^{k}\right]^{-1}=\left[\frac{\mathrm{TGR}_{\mathrm{t}+1}^{\mathrm{k}}\left(\mathrm{x}_{\mathrm{t}+1}, \mathrm{y}_{\mathrm{t}+1}\right)}{\mathrm{TGR}_{\mathrm{t}}^{\mathrm{k}}\left(\mathrm{x}_{\mathrm{t}}, \mathrm{y}_{\mathrm{t}}\right)} \times \frac{\mathrm{TGR}_{\mathrm{t}}^{\mathrm{k}}\left(\mathrm{x}_{\mathrm{t}+1}, \mathrm{y}_{\mathrm{t}+1}\right)}{\mathrm{TGR}_{\mathrm{t}+1}^{\mathrm{k}}\left(\mathrm{x}_{\mathrm{t}}, \mathrm{y}_{\mathrm{t}}\right)}\right]^{1 / 2}
$$

Substituting Eq. (16a) into Eq. (19), we get: 


$$
\mathrm{MMPI}_{\mathrm{t}, \mathrm{t}+1}=\mathrm{GMPI}_{\mathrm{t}, \mathrm{t}+1} \times\left[\mathrm{catch}-\mathrm{up}_{\mathrm{t}, \mathrm{t}+1}^{\mathrm{k}}\right]^{-1}
$$

and

$$
\text { catch }-u_{\mathrm{t}, \mathrm{t}+1}^{\mathrm{k}}=\frac{\mathrm{GMPI}_{\mathrm{t}, \mathrm{t}+1}}{\mathrm{MMPI}_{\mathrm{t}, \mathrm{t}+1}}
$$

However, on detailed inspection, it might be found that the implication of catch-up captured by Eq. (20) seems worthy of further expression. Specifically, the meaning of the first term on the right-hand side of the equal sign in Eq. (20) is more definite. The numerator is a technology gap ratio (TGR) lying between the metafrontier and the group frontier of period $t+1$ measured at the input-output point of period $t+1$, whereas the denominator is a TGR lying between the metafrontier and the group frontier of period $t$ measured at the input-output point of period $t$. However, as for the second term, the numerator is a TGR lying between the metafrontier and the group frontier of period $t$ measured at the inputoutput point of period $t+1$, whereas the denominator is the TGR lying between the metafrontier and the group frontier of period $t+1$ measured at the input-output point of period $t$. Therefore, the first term refers to the change in TGR from period $t$ to period $t+1$, whereas the second term measures the change in TGR from period $t+1$ to period $t$. The implications of these two terms are just the opposite, in which case the geometric mean of these two terms would be perplexing. In view of the ambiguity, this paper attempts to adapt Eqs. (19-22) as follows:

$$
\mathrm{MMPI}_{\mathrm{t}, \mathrm{t}+1}=\mathrm{TEC}_{\mathrm{t}, \mathrm{t}+1}^{\mathrm{k}} \times \mathrm{TC}_{\mathrm{t}, \mathrm{t}+1}^{\mathrm{k}} \times \mathrm{TGRC}_{\mathrm{t}, \mathrm{t}+1}^{\mathrm{k}} \text {. }
$$

Substituting Eq. 16a into Eq. 23 we then have:

$$
\mathrm{MMPI}_{\mathrm{t}, \mathrm{t}+1}=\mathrm{GMPI}_{\mathrm{t}, \mathrm{t}+1} \times \mathrm{TGRC}_{\mathrm{t}, \mathrm{t}+1}^{\mathrm{k}} \text {, }
$$

and

$$
\operatorname{TGRC}_{t, t+1}^{k}=\frac{\text { MMPI }_{t, t+1}}{\operatorname{GMPI}_{t, t+1}},
$$

where

$$
\mathrm{TGRC}_{\mathrm{t}, \mathrm{t}+1}^{\mathrm{k}}=\left[\frac{\mathrm{TGR}_{\mathrm{t}+1}^{\mathrm{k}}\left(\mathrm{x}_{\mathrm{t}+1}, \mathrm{y}_{\mathrm{t}+1}\right)}{\mathrm{TGR}_{\mathrm{t}}^{\mathrm{k}}\left(\mathrm{x}_{\mathrm{t}}, \mathrm{y}_{\mathrm{t}}\right)} \times \frac{\mathrm{TGR}_{\mathrm{t}}^{\mathrm{k}}\left(\mathrm{x}_{\mathrm{t}+1}, \mathrm{y}_{\mathrm{t}+1}\right)}{\mathrm{TGR}_{\mathrm{t}+1}^{\mathrm{k}}\left(\mathrm{x}_{\mathrm{t}}, \mathrm{y}_{\mathrm{t}}\right)}\right]^{1 / 2} \text {. }
$$

There are two implications embedded in Eq. (27). First, the first term on the right-hand side of the equal sign signifies the change in TGR from period $t$ to $t+1$, measured at the input-output points of period $t$ and $t+1$. A value larger than unity implies the shrinkage of the technology gap (i.e., an increase in TGR) clearly, such a measure refers to the 'catch-up' actually faced by a specific firm. Because it purely captures the catch-up in technology without the ingredients of technical inefficiency from the view of a group frontier, it is worth being singled out and dubbed pure technological catch-up (PTCU):

$$
\operatorname{PTCU}_{\mathrm{t}, \mathrm{t}+1}^{\mathrm{k}}=\frac{\operatorname{TGR}_{\mathrm{t}+1}^{\mathrm{k}}\left(\mathrm{x}_{\mathrm{t}+1}, \mathrm{y}_{\mathrm{t}+1}\right)}{\mathrm{TGR}_{\mathrm{t}}^{\mathrm{k}}\left(\mathrm{x}_{\mathrm{t}}, \mathrm{y}_{\mathrm{t}}\right)}
$$

Moreover, the second term of Eq. (27) is a geometric mean comprised of two inverse changes in TGR from period $t$ to $t+1$, regarding the input-output points of period $t+1$ and period $t$ as the reference positions. Thus, this term implies that the change in a whole band of TGR is located between the group frontiers and the metafrontier, which is similar to the concept expressed by O'Donnell et al. (2008). A value less than unity implies the shrinkage of the whole band of the technology gap (i.e., an increase in the whole set of TGR). This term could also be dubbed frontier catch-up (FCU):

$$
\mathrm{FCU}_{\mathrm{t}, \mathrm{t}+1}^{\mathrm{k}}=\left[\frac{\mathrm{TGR}_{\mathrm{t}}^{\mathrm{k}}\left(\mathrm{x}_{\mathrm{t}+1}, \mathrm{y}_{\mathrm{t}+1}\right)}{\mathrm{TGR}_{\mathrm{t}+1}^{\mathrm{k}}\left(\mathrm{x}_{\mathrm{t}+1}, \mathrm{y}_{\mathrm{t}+1}\right)} \times \frac{\mathrm{TGR}_{\mathrm{t}}^{\mathrm{k}}\left(\mathrm{x}_{\mathrm{t}}, \mathrm{y}_{\mathrm{t}}\right)}{\mathrm{TGR}_{\mathrm{t}+1}^{\mathrm{k}}\left(\mathrm{x}_{\mathrm{t}}, \mathrm{y}_{\mathrm{t}}\right)}\right] 1 / 2 .
$$

For a more intuitive illustration, we further adapt Eq. (29) as: 


$$
\left[\frac{\operatorname{TGR}_{t}^{k}\left(x_{t+1}, y_{t+1}\right)}{\operatorname{TGR}_{t+1}^{k}\left(x_{t+1}, y_{t+1}\right)} \times \frac{\operatorname{TGR}_{t}^{k}\left(x_{t}, y_{t}\right)}{\operatorname{TGR}_{t+1}^{k}\left(x_{t}, y_{t}\right)}\right]^{\frac{1}{2}}=\left[\frac{\frac{D_{t}^{*}\left(x_{t+1}, y_{t+1}\right)}{D_{t+1}^{*}\left(x_{t+1}, y_{t+1}\right)}}{\frac{D_{t}^{k}\left(x_{t+1}, y_{t+1}\right)}{D_{t}^{k}\left(x_{t+1}, y_{t+1}\right)}} \times \frac{\frac{D_{t}^{*}\left(x_{t}, y_{t}\right)}{D_{t+1}^{*}\left(x_{t}, y_{t}\right)}}{\frac{D_{t}^{k}\left(x_{t}, y_{t}\right)}{D_{t+1}^{k}\left(x_{t}, y_{t}\right)}}\right]^{1 / 2}=\frac{T_{t, t+1}^{*}}{T_{t, t+1}^{k}}
$$

Therefore, Eq. (29) can also be simply calculated by Eq. (30). Then, we know that the MMPI and its decompositions can be adapted as:

$$
\mathrm{MMPI}_{\mathrm{t}, \mathrm{t}+1}=\mathrm{TEC}_{\mathrm{t}, \mathrm{t}+1}^{\mathrm{k}} \times \mathrm{TC}_{\mathrm{t}, \mathrm{t}+1}^{\mathrm{k}} \times \mathrm{PTCU}_{\mathrm{t}, \mathrm{t}+1}^{\mathrm{k}} \times \mathrm{FCU}_{\mathrm{t}, \mathrm{t}+1}^{\mathrm{k}}
$$

\section{Research findings}

\subsection{Data Collection}

Table 2

\begin{tabular}{|c|c|c|c|c|c|c|c|c|c|c|c|c|c|c|c|}
\hline & & 1 & 2 & 3 & 4 & 5 & 6 & 7. & 8 & 9. & 10. & 11. & 12. & 13. & 14. \\
\hline \multirow{4}{*}{$\begin{array}{l}\text { East Asia } \\
\text { and Pacific }\end{array}$} & Mean & 0.35 & 0.30 & 0.45 & 0.41 & 0.36 & 0.52 & 0.34 & 0.65 & 0.36 & 0.58 & 0.49 & 0.47 & 0.37 & 0.53 \\
\hline & STD & 0.20 & 0.23 & 0.27 & 0.20 & 0.18 & 0.23 & 0.30 & 0.25 & 0.15 & 0.28 & 0.33 & 0.34 & 0.27 & 0.27 \\
\hline & Min & 0.13 & 0.00 & 0.01 & 0.09 & 0.11 & 0.25 & 0.00 & 0.19 & 0.12 & 0.21 & 0.07 & 0.08 & 0.04 & 0.12 \\
\hline & Max & 0.95 & 1.00 & 0.80 & 0.74 & 0.75 & 1.00 & 0.97 & 1.00 & 0.64 & 1.00 & 1.00 & 1.00 & 1.00 & 0.96 \\
\hline \multirow{4}{*}{$\begin{array}{l}\text { Europe } \\
\text { and } \\
\text { central } \\
\text { Asia }\end{array}$} & Mean & 0.48 & 0.55 & 0.43 & 0.43 & 0.49 & 0.54 & 0.56 & 0.51 & 0.46 & 0.48 & 0.53 & 0.48 & 0.62 & 0.52 \\
\hline & STD & 0.29 & 0.22 & 0.31 & 0.21 & 0.25 & 0.28 & 0.26 & 0.19 & 0.26 & 0.28 & 0.25 & 0.17 & 0.26 & 0.21 \\
\hline & Min & 0.10 & 0.11 & 0.01 & 0.11 & 0.09 & 0.14 & 0.12 & 0.18 & 0.14 & 0.05 & 0.08 & 0.13 & 0.08 & 0.15 \\
\hline & Max & 1.00 & 1.00 & 0.98 & 1.00 & 1.00 & 1.00 & 1.00 & 1.00 & 0.98 & 1.00 & 1.00 & 0.83 & 1.00 & 1.00 \\
\hline \multirow{4}{*}{$\begin{array}{l}\text { Latin } \\
\text { America } \\
\text { and } \\
\text { Caribbean }\end{array}$} & Mean & 0.37 & 0.40 & 0.27 & 0.36 & 0.30 & 0.26 & 0.17 & 0.31 & 0.30 & 0.29 & 0.16 & 0.26 & 0.24 & 0.17 \\
\hline & STD & 0.21 & 0.26 & 0.25 & 0.16 & 0.16 & 0.14 & 0.11 & 0.20 & 0.14 & 0.22 & 0.09 & 0.20 & 0.16 & 0.12 \\
\hline & Min & 0.05 & 0.09 & 0.02 & 0.04 & 0.09 & 0.02 & 0.02 & 0.09 & 0.08 & 0.05 & 0.03 & 0.05 & 0.02 & 0.04 \\
\hline & Max & 0.93 & 1.00 & 1.00 & 0.77 & 0.71 & 0.67 & 0.43 & 1.00 & 0.83 & 1.00 & 0.33 & 0.92 & 0.70 & 0.65 \\
\hline \multirow{4}{*}{$\begin{array}{l}\text { Middle } \\
\text { East and } \\
\text { North } \\
\text { America }\end{array}$} & Mean & 0.43 & 0.40 & 0.30 & 0.52 & 0.46 & 0.47 & 0.31 & 0.56 & 0.32 & 0.43 & 0.37 & 0.57 & 0.37 & 0.62 \\
\hline & STD & 0.22 & 0.21 & 0.22 & 0.21 & 0.25 & 0.20 & 0.22 & 0.25 & 0.19 & 0.24 & 0.24 & 0.27 & 0.17 & 0.27 \\
\hline & Min & 0.09 & 0.14 & 0.02 & 0.09 & 0.09 & 0.16 & 0.08 & 0.13 & 0.10 & 0.13 & 0.09 & 0.19 & 0.15 & 0.26 \\
\hline & Max & 0.78 & 0.86 & 0.66 & 0.80 & 0.99 & 0.79 & 1.00 & 1.00 & 0.83 & 1.00 & 1.00 & 1.00 & 0.66 & 1.00 \\
\hline \multirow{4}{*}{$\begin{array}{l}\text { North } \\
\text { America }\end{array}$} & Mean & 0.93 & 0.87 & 0.87 & 0.53 & 0.86 & 0.87 & 0.71 & 0.96 & 0.84 & 0.85 & 0.79 & 0.85 & 0.99 & 1.00 \\
\hline & STD & 0.07 & 0.13 & 0.11 & 0.00 & 0.01 & 0.10 & 0.10 & 0.04 & 0.13 & 0.06 & 0.14 & 0.15 & 0.01 & 0.00 \\
\hline & Min & 0.85 & 0.73 & 0.75 & 0.52 & 0.85 & 0.77 & 0.61 & 0.92 & 0.71 & 0.79 & 0.66 & 0.69 & 0.98 & 1.00 \\
\hline & Max & 1.00 & 1.00 & 0.98 & 0.53 & 0.88 & 0.97 & 0.81 & 1.00 & 0.97 & 0.91 & 0.93 & 1.00 & 1.00 & 1.00 \\
\hline \multirow[t]{4}{*}{ South Asia } & Mean & 0.28 & 0.09 & 0.14 & 0.12 & 0.19 & 0.25 & 0.10 & 0.15 & 0.33 & 0.36 & 0.32 & 0.22 & 0.15 & 0.10 \\
\hline & STD & 0.01 & 0.04 & 0.15 & 0.01 & 0.01 & 0.08 & 0.05 & 0.05 & 0.20 & 0.25 & 0.17 & 0.08 & 0.09 & 0.05 \\
\hline & Min & 0.27 & 0.04 & 0.02 & 0.10 & 0.18 & 0.11 & 0.03 & 0.10 & 0.15 & 0.03 & 0.15 & 0.12 & 0.01 & 0.05 \\
\hline & Max & 0.29 & 0.16 & 0.39 & 0.14 & 0.20 & 0.32 & 0.15 & 0.23 & 0.65 & 0.74 & 0.59 & 0.34 & 0.28 & 0.17 \\
\hline \multirow{4}{*}{$\begin{array}{l}\text { Sub } \\
\text { Sharan } \\
\text { Africa }\end{array}$} & Mean & 0.36 & 0.08 & 0.12 & 0.28 & 0.26 & 0.22 & 0.15 & 0.16 & 0.23 & 0.17 & 0.20 & 0.26 & 0.14 & 0.11 \\
\hline & STD & 0.13 & 0.06 & 0.16 & 0.14 & 0.16 & 0.10 & 0.04 & 0.10 & 0.11 & 0.14 & 0.12 & 0.12 & 0.13 & 0.08 \\
\hline & Min & 0.14 & 0.01 & 0.02 & 0.05 & 0.05 & 0.05 & 0.05 & 0.03 & 0.05 & 0.05 & 0.02 & 0.02 & 0.02 & 0.03 \\
\hline & Max & 0.70 & 0.32 & 0.75 & 0.59 & 0.71 & 0.39 & 0.23 & 0.45 & 0.63 & 0.63 & 0.50 & 0.55 & 0.50 & 0.43 \\
\hline \multirow[t]{4}{*}{ Overall } & Mean & 0.45 & 0.38 & 0.37 & 0.38 & 0.42 & 0.45 & 0.33 & 0.47 & 0.41 & 0.45 & 0.41 & 0.44 & 0.41 & 0.43 \\
\hline & STD & 0.24 & 0.28 & 0.29 & 0.20 & 0.24 & 0.26 & 0.27 & 0.26 & 0.22 & 0.28 & 0.27 & 0.25 & 0.29 & 0.29 \\
\hline & Min & 0.05 & 0.00 & 0.01 & 0.04 & 0.05 & 0.02 & 0.00 & 0.03 & 0.05 & 0.03 & 0.02 & 0.02 & 0.01 & 0.03 \\
\hline & Max & 1.00 & 1.00 & 1.00 & 1.00 & 1.00 & 1.00 & 1.00 & 1.00 & 0.98 & 1.00 & 1.00 & 1.00 & 1.00 & 1.00 \\
\hline
\end{tabular}

Pure Output-Oriented Data Envelopment Analysis Model for entrepreneurship ecosystem

1. Opportunity Perception 2. Startup Skills 3. Risk Acceptance 4. Networking 5. Cultural Support 6. Opportunity Startup 7. Technology Absorption

8. Human Capital 9. Competition 10. Product Innovation 11. Process Innovation 12. High Growth 13. Internationalization 14. Risk Capital

Data needed for 132 countries have been collected in seven geographic regions during 2016 and 2017, based on the Global Entrepreneurship index, published by the Global Entrepreneurship and Development Institute. The summary of data related to 2017 is shown in Table 2.

\subsection{Calculation of Distance Functions}

To calculate the performance changes based on the mentioned equations, it is necessary to calculate distant functions. With regard to the existing geographic groups, the distance functions must be calculated for each group. The calculation of the distance functions of group $\mathrm{k}$ is made based on Eq. (3). We know that each distance function is a DEA model. Then, it is necessary to form a metafrontier group, which includes the total data of the seven groups, which are given in equations 5, 6, and 7. After forming a metafrontier group, its distance function must be calculated, which is done in accordance with the Eq. 
(8). After grouping, distance function for the each group is calculated. In Table 3, the values of the distance functions with the Meta Frontier can be locally seen for Iran. It should be noted that in all equations $t$ and $t+1$ stand for 2016 and 2017, respectively.

Table 3

Values of distance functions with Meta Frontier locally for Iran

$$
\text { META FRONTIER (*) }
$$

LOCAL FRONTIER (k)
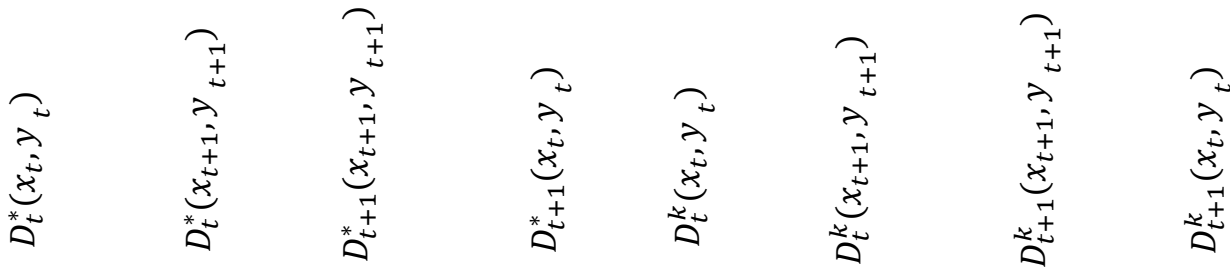

Iran, Islamic Rep.

0.71

0.71

0.62

0.62

0.95

0.90

0.79

0.79

\subsection{Calculating the group Malmquist index and its metafrontier and components}

In the next step, after calculating the distance functions, Malmquist index should be calculated. Therefore, in order to clarify the issue, the calculations related to the Islamic Republic of Iran is shown in detail.

$$
0 \leq T G R_{t}^{k}\left(x_{t}, y_{t}\right)=\frac{D_{t}^{*}\left(x_{t}, y_{t}\right)}{D_{t}^{k}\left(x_{t}, y_{t}\right)}=\frac{T E_{t}^{*}\left(x_{t}, y_{t}\right)}{T E_{t}^{k}\left(x_{t}, y_{t}\right)} \leq 1
$$

According to the above equation, in order to calculate the gap ratio of technology, the value of the metafrontier function should be divided by the group distance function, which is calculated for the Islamic Republic of Iran below.

$$
\begin{aligned}
& \operatorname{TGR}_{t}^{k}\left(x_{t}, y_{t}\right)=\frac{D_{t}^{*}\left(x_{t}, y_{t}\right)}{D_{t}^{k}\left(x_{t}, y_{t}\right)}=0.75 \\
& \operatorname{TGR}_{t}^{k}\left(x_{t+1}, y_{t+1}\right)=\frac{D_{t}^{*}\left(x_{t+1}, y_{+1}\right)}{D_{t}^{k}\left(x_{t+1}, y_{t+1}\right)}=0.79 \\
& \operatorname{TGR}_{t+1}^{k}\left(x_{t+1}, y_{t+1}\right)=\frac{D_{t+1}^{*}\left(x_{t+1}, y_{t+1}\right)}{D_{t+1}^{k}\left(x_{t+1}, y_{t+1}\right)}=0.78 \\
& \operatorname{TGR}_{t+1}^{k}\left(x_{t}, y_{t}\right)=\frac{D_{t+1}^{*}\left(x_{t}, y_{t}\right)}{D_{t+1}^{k}\left(x_{t}, y_{t}\right)}=0.78
\end{aligned}
$$

The value of the technology gap ratio can be between zero and one, and the closer value to 1 , the smaller gap between the group and metafrontier and there is a greater similarity between the metafrontier and the group and better technical standards are considered, so according to above calculation, the gap between metafrontier and the group is relatively high for Iran. This means that the technical standards are not perfectly implemented. Of course, there was some improvement for decreasing the gap in 2017 compared to 2016. After calculating the technology gap ratio, we need to calculate the group Malmquist index and its components. The following equations calculate the indices.

$$
M P I_{t, t+1}^{k}\left(x_{t}, y_{t}, x_{t+1}, y_{t+1}\right)=\frac{D_{t+1}^{k}\left(x_{t+1}, y_{t+1}\right)}{D_{t}^{k}\left(x_{t}, y_{t}\right)} \times\left[\frac{D_{t}^{k}\left(x_{t+1}, y_{t+1}\right)}{D_{t+1}^{k}\left(x_{t+1}, y_{t+1}\right)} \times \frac{D_{t}^{k}\left(x_{t}, y_{t}\right)}{D_{t+1}^{k}\left(x_{t}, y_{t}\right)}\right]^{1 / 2}
$$

In this equation, the first expression in the right side is the technical efficiency change, and the second expression is the technical change. For further clarity, the calculation of this index has been done using the data of Iran Mineral Institute. 


$$
\begin{aligned}
& T E C=\frac{D_{t+1}^{k}\left(x_{t+1}, y_{t+1}\right)}{D_{t}^{k}\left(x_{t}, y_{t}\right)}=0.83 \\
& T C=\left[\frac{D_{t}^{k}\left(x_{t+1}, y_{t+1}\right)}{D_{t+1}^{k}\left(x_{t+1}, y_{t+1}\right)} \times \frac{D_{t}^{k}\left(x_{t}, y_{t}\right)}{D_{t+1}^{k}\left(x_{t}, y_{t}\right)}\right]^{1 / 2}=\left[\frac{0.9}{0.79} \times \frac{0.95}{0.79}\right]^{1 / 2}=1.26 \\
& M P I_{t, t+1}^{k}\left(x_{t}, y_{t}, x_{t+1}, y_{t+1}\right)=0.83 * 1.26=1.05
\end{aligned}
$$

The above index known as the Group Malmquist Productivity Index (GMPI), which is presented in the following equation.

$$
G M P I_{t, t+1}=T E C_{t, t+1}^{k} \times T C_{t, t+1}^{k}=1.05
$$

As it is obvious, if the value of technical efficiency change and technical changes would be greater than 1 , it can be concluded that the technical efficiency and technology have been improved in the studied period, and if these values would be less than 1, it can be concluded that the technical and technology efficiency have been reduced. Given the issue that the value of change in technical efficiency is less than 1, it means that the technical efficiency has decreased from 2016 to 2017. But the results of calculating the technology change indicate that there was a 0.26 improvement in technology from 2016 to 2017. Also, by looking at the group Malmquist index, in the Malmquist index is improved by $0.05 \%$, which is due to the technology improvement, not the technical efficiency improvement. After calculating the group Malmquist index, it is necessary to calculate the metafrontier Malmquist index, which is presented in the following equations.

$$
M M P I_{t, t+1}\left(x_{t}, y_{t}, x_{t+1}, y_{t+1}\right)=\frac{D_{t+1}^{*}\left(x_{t+1}, y_{t+1}\right)}{D_{t}^{*}\left(x_{t}, y_{t}\right)} \times\left[\frac{D_{t}^{*}\left(x_{t+1}, y_{t+1}\right)}{D_{t+1}^{*}\left(x_{t+1}, y_{t+1}\right)} \times \frac{D_{t}^{*}\left(x_{t}, y_{t}\right)}{D_{t+1}^{*}\left(x_{t}, y_{t}\right)}\right]^{1 / 2}
$$

Similarly, in the above equation, the first term is TEC* and the second term is TC*. The calculation of the metafrontier Malmquist index for the Islamic Republic of Iran is presented in the following equations.

$$
\begin{aligned}
& T E C^{*}=\frac{D_{t+1}^{*}\left(x_{t+1}, y_{t+1}\right)}{D_{t}^{*}\left(x_{t}, y_{t}\right)}=\frac{0.62}{0.71}=0.87 \\
& T C^{*}=\left[\frac{D_{t}^{*}\left(x_{t+1}, y_{t+1}\right)}{D_{t+1}^{*}\left(x_{t+1}, y_{t+1}\right)} \times \frac{D_{t}^{*}\left(x_{t}, y_{t}\right)}{D_{t+1}^{*}\left(x_{t}, y_{t}\right)}\right]^{1 / 2}=\left[\frac{0.71}{0.62} \times \frac{0.71}{0.62}\right]^{1 / 2}=1.24 \\
& M M P I_{t, t+1}=1.08
\end{aligned}
$$

The results of calculating the metafrontier Malmquist index also indicate that the technical efficiency decreased from 2016 to 2017. But the results from the calculation of technology change indicate that there was a 0.24 improvement in technology. Also, study of the Malmquist Group index showed that change in the Malmquist index leads to a 0.08 growth, which is due to the technological changes.

By resetting the metafrontier Malmquist index, new elements have been emerged that are presented in the equation below.

$$
\begin{aligned}
& M M P I_{t, t+1}=T E C_{t, t+1}^{k} c T C_{t, t+1}^{k} \times\left[\text { catch }-u p_{t, t+1}^{k}\right]^{-1} \\
& {\left[\text { catch }-u p_{t, t+1}^{k}\right]^{-1}=\left[\frac{T G R_{t+1}^{k}\left(x_{t+1}, y_{t+1}\right)}{T G R_{t}^{k}\left(x_{t}, y_{t}\right)} \times \frac{T G R_{t}^{k}\left(x_{t+1}, y_{t+1}\right)}{T G R_{t+1}^{k}\left(x_{t}, y_{t}\right)}\right]^{1 / 2}}
\end{aligned}
$$

As it can be seen in the above equations, a new term emerges in the metafrontier equation, called the technology's backwardness compensation. In other words, the term is the change in the technology gap ratio. 


$$
\begin{aligned}
& {\left[\text { catch }-u p_{t, t+1}^{k}\right]=\left[\frac{0.75}{0.78} \times \frac{0.79}{0.78}\right]^{1 / 2}=0.97} \\
& M M P I_{t, t+1}=0.83 \times 1.26 \times\left(\frac{1}{0.97}\right)=1.08
\end{aligned}
$$

As it was seen, Eq. (23) to Eq. (25) have analyzed the metafrontier Malmquist index, which indicates further details.

$$
\begin{gathered}
T G R C_{t, t+1}^{k}=\frac{M M P I_{t, t+1}}{G M P I_{t, t+1}}=\frac{1.08}{1.05}=1.03 \\
T G R C_{t, t+1}^{k}=\left[\frac{T G R_{t+1}^{k}\left(x_{t+1}, y_{t+1}\right)}{T G R_{t}^{k}\left(x_{t}, y_{t}\right)} \times \frac{T G R_{t}^{k}\left(x_{t+1}, y_{t+1}\right)}{T G R_{t+1}^{k}\left(x_{t}, y_{t}\right)}\right]^{1 / 2}=\left[\frac{0.78}{0.75} \times \frac{0.78}{0.79}\right]^{1 / 2}=1.03 \\
M M P I_{t, t+1}=T E C_{t, t+1}^{k} \times T C_{t, t+1}^{k} \times T G R C_{t, t+1}^{k}=0.83 * 1.26 * 1.03 \\
M M P I_{t, t+1}=G M P I_{t, t+1} \times T G R C_{t, t+1}^{k}=1.05 * 1.03
\end{gathered}
$$

In the above equations, TGRC has been calculated in two different ways, which provides more information by further analysis of the technology gap ratio changes.

The TGRC is decomposed into two indices including pure technical backwardness compensation and

\begin{tabular}{|c|c|c|c|c|c|c|c|c|c|c|c|}
\hline & & TEC $^{*}$ & TC $^{*}$ & TEC $^{k}$ & TC $^{k}$ & GMPI & Cach-Up & TGRC & MMPI & PTCU & FCU \\
\hline \multirow{16}{*}{$\begin{array}{c}\text { EAST } \\
\text { ASIA AND } \\
\text { PACIFIC }\end{array}$} & Australia & 1.00 & 1.05 & 1.00 & 1.14 & 1.14 & 1.10 & 0.91 & 1.03 & 1.00 & 0.91 \\
\hline & Brunei Darussalam & 1.00 & 1.00 & 1.00 & 1.00 & 1.00 & 1.02 & 0.98 & 0.98 & 1.00 & 0.98 \\
\hline & Cambodia & 0.78 & 1.65 & 0.60 & 1.67 & 1.00 & 1.06 & 0.95 & 0.95 & 1.30 & 0.73 \\
\hline & China & 1.09 & 0.86 & 1.13 & 0.83 & 0.94 & 1.09 & 0.92 & 0.86 & 0.96 & 0.96 \\
\hline & Hong Kong & 1.00 & 1.01 & 1.00 & 1.13 & 1.13 & 1.04 & 0.96 & 1.09 & 1.00 & 0.96 \\
\hline & Indonesia & 1.01 & 0.99 & 1.24 & 0.70 & 0.88 & 1.00 & 1.00 & 0.88 & 0.81 & 1.24 \\
\hline & Japan & 1.00 & 1.01 & 1.00 & 1.11 & 1.11 & 1.01 & 0.99 & 1.09 & 1.00 & 0.99 \\
\hline & Korea, Rep. & 1.05 & 0.94 & 1.00 & 1.10 & 1.10 & 1.06 & 0.94 & 1.04 & 1.05 & 0.90 \\
\hline & Lao PDR & 0.67 & 2.26 & 0.58 & 1.56 & 0.91 & 1.04 & 0.96 & 0.87 & 1.16 & 0.83 \\
\hline & Malaysia & 1.04 & 1.01 & 1.00 & 1.00 & 1.00 & 1.08 & 0.93 & 0.93 & 1.04 & 0.89 \\
\hline & Myanmar & 1.08 & 0.86 & 1.06 & 2.25 & 2.40 & 1.00 & 1.00 & 2.40 & 1.01 & 0.99 \\
\hline & Philippines & 0.91 & 1.21 & 0.97 & 1.04 & 1.01 & 1.04 & 0.96 & 0.97 & 0.94 & 1.02 \\
\hline & Singapore & 1.00 & 1.05 & 1.00 & 1.05 & 1.05 & 1.03 & 0.97 & 1.02 & 1.00 & 0.97 \\
\hline & Taiwan, China & 1.00 & 1.12 & 1.00 & 1.00 & 1.00 & 1.07 & 0.94 & 0.94 & 1.00 & 0.94 \\
\hline & Thailand & 0.80 & 1.52 & 0.77 & 1.30 & 1.01 & 1.04 & 0.97 & 0.97 & 1.04 & 0.93 \\
\hline & Vietnam & 0.68 & 2.36 & 0.61 & 1.68 & 1.03 & 1.02 & 0.98 & 1.01 & 1.11 & 0.88 \\
\hline
\end{tabular}
the backwardness compensation boundary.

$$
\begin{aligned}
& \operatorname{PTCU}_{t, t+1}^{k}=\frac{\mathrm{TGR}_{\mathrm{t}+1}^{\mathrm{k}}\left(\mathrm{x}_{\mathrm{t}+1}, \mathrm{y}_{\mathrm{t}+1}\right)}{\mathrm{TGR}_{\mathrm{t}}^{\mathrm{k}}\left(\mathrm{x}_{\mathrm{t}}, \mathrm{y}_{\mathrm{t}}\right)}=\frac{0.78}{0.75}=1.05 \\
& \operatorname{FCU}_{\mathrm{t}, \mathrm{t}+1}^{\mathrm{k}}=\left[\frac{\mathrm{TGR}_{\mathrm{t}}^{\mathrm{k}}\left(\mathrm{x}_{\mathrm{t}+1}, \mathrm{y}_{\mathrm{t}+1}\right)}{\mathrm{TGR}_{\mathrm{t}+1}^{\mathrm{k}}\left(\mathrm{x}_{\mathrm{t}+1}, \mathrm{y}_{\mathrm{t}+1}\right)} \times \frac{\mathrm{TGR}_{\mathrm{t}}^{\mathrm{k}}\left(\mathrm{x}_{\mathrm{t}}, \mathrm{y}_{\mathrm{t}}\right)}{\mathrm{TGR}_{\mathrm{t}+1}^{\mathrm{k}}\left(\mathrm{x}_{\mathrm{t}}, \mathrm{y}_{\mathrm{t}}\right)}\right]^{1 / 2}=\left[\frac{0.78}{0.78} \times \frac{0.75}{0.79}\right]^{1 / 2}=0.98 \\
& \text { Or } \quad \operatorname{FCU}_{\mathrm{t}, \mathrm{t}+1}^{\mathrm{k}}=\frac{\mathrm{TC}_{\mathrm{t}, \mathrm{t}+1}^{\mathrm{k}}}{\mathrm{TC}_{\mathrm{t}, \mathrm{t}+1}^{\mathrm{k}}}=\frac{1.24}{1.26}=0.98
\end{aligned}
$$

Table 4

Calculations of Productivity Changes using the metafrontier Malmquist Method for EAST ASIA AND PACIFIC

If PTCU shows the values greater than 1, the technology gap is reduced. Therefore, since the PTCU is greater than 1, it can be concluded that the technology gap has been somewhat reduced. If FCU is greater than 1, it means that technological improvements have been made and given the fact that it 
represents a value less than one, then the country's potential for the improvement of the entrepreneurship ecosystem has been decreased. After calculating these indices, the calculation of the metafrontier Malmquist index is made using the technical efficiency change, technical change, compensation for the pure technical backwardness, and backwardness compensation boundary that are presented in the equation below.

$M M P I_{t, t+1}=0.83 * 1.26 * 0.98 * 1.05=1.08$

As shown in Table 4 to Table 10, the calculations for 132 countries have also been made.

Table 5

Calculations of Productivity Changes using the metafrontier Malmquist Method for Europe and Central Asia

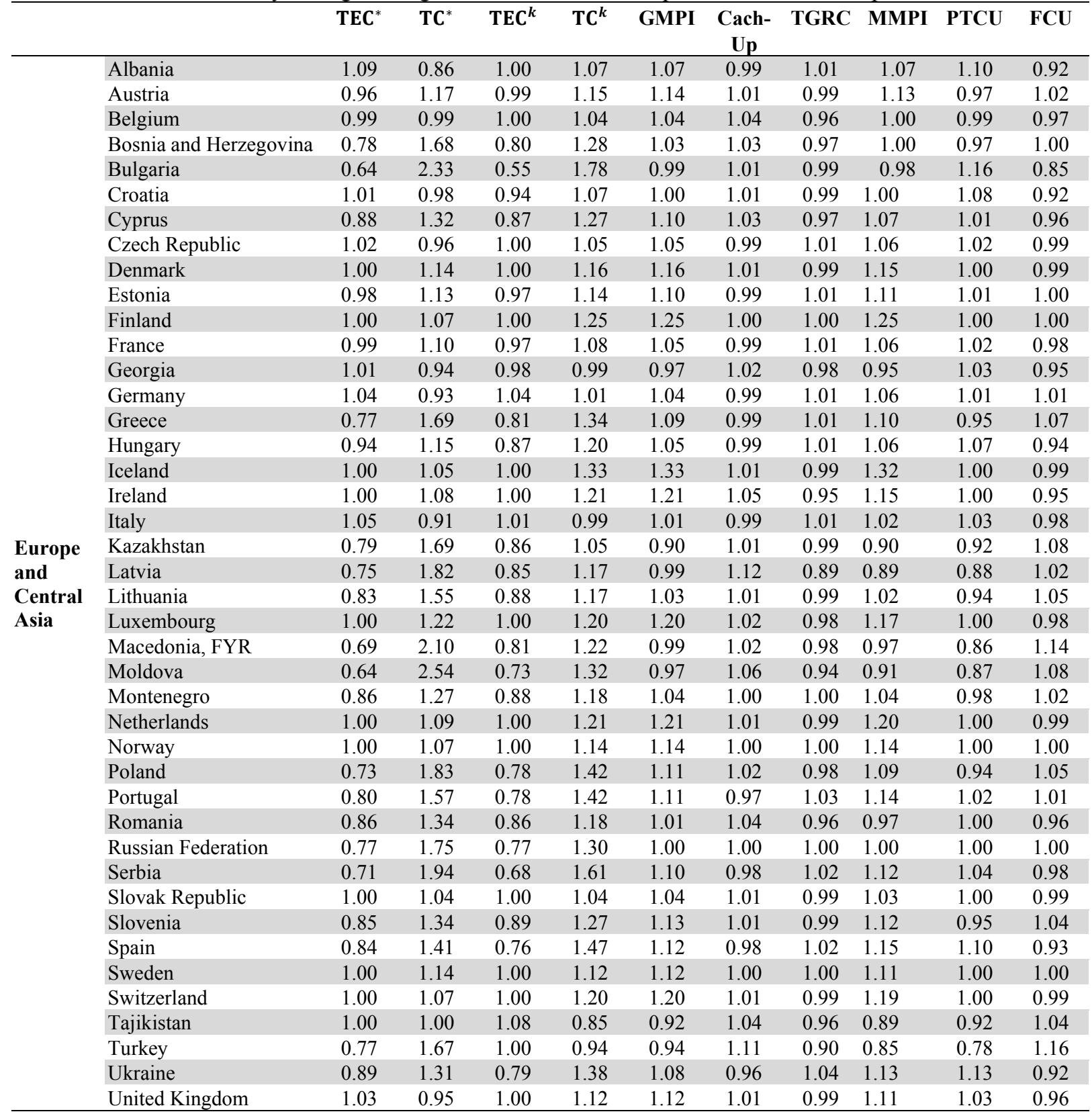


Table 6

Calculations of Productivity Changes using the metafrontier Malmquist Method for Latin America and The Caribbean

\begin{tabular}{|c|c|c|c|c|c|c|c|c|c|c|c|}
\hline & & TEC $^{*}$ & TC* $^{*}$ & TEC $^{k}$ & TC $^{k}$ & GMPI & $\begin{array}{c}\text { Cach- } \\
\text { Up }\end{array}$ & TGRC & MMPI & PTCU & FCU \\
\hline \multirow{25}{*}{$\begin{array}{c}\text { Latin } \\
\text { America } \\
\text { and The } \\
\text { Caribbean }\end{array}$} & Argentina & 0.72 & 1.93 & 0.89 & 0.99 & 0.88 & 1.08 & 0.93 & 0.82 & 0.81 & 1.15 \\
\hline & Barbados & 1.02 & 0.96 & 1.00 & 1.02 & 1.02 & 1.11 & 0.90 & 0.92 & 1.02 & 0.89 \\
\hline & Belize & 0.53 & 3.58 & 0.46 & 2.16 & 0.99 & 1.00 & 1.00 & 0.99 & 1.16 & 0.86 \\
\hline & Bolivia & 0.80 & 1.59 & 0.72 & 1.39 & 1.00 & 1.01 & 0.99 & 0.99 & 1.11 & 0.89 \\
\hline & Brazil & 0.45 & 4.87 & 0.62 & 1.48 & 0.92 & 1.04 & 0.96 & 0.89 & 0.73 & 1.32 \\
\hline & Chile & 1.00 & 1.09 & 1.00 & 1.24 & 1.24 & 1.14 & 0.88 & 1.09 & 1.00 & 0.88 \\
\hline & Colombia & 0.92 & 1.31 & 1.00 & 1.05 & 1.05 & 1.10 & 0.91 & 0.96 & 0.92 & 0.99 \\
\hline & Costa Rica & 1.10 & 1.01 & 1.04 & 0.83 & 0.87 & 0.95 & 1.05 & 0.91 & 1.05 & 1.00 \\
\hline & Dominican Republic & 0.84 & 1.19 & 0.92 & 0.96 & 0.88 & 1.16 & 0.86 & 0.76 & 0.91 & 0.94 \\
\hline & Ecuador & 0.81 & 1.56 & 0.77 & 1.16 & 0.89 & 0.98 & 1.02 & 0.91 & 1.05 & 0.97 \\
\hline & El Salvador & 0.64 & 2.51 & 0.65 & 1.45 & 0.94 & 1.02 & 0.98 & 0.92 & 0.99 & 0.99 \\
\hline & Guatemala & 1.00 & 1.00 & 0.88 & 1.09 & 0.96 & 1.01 & 0.99 & 0.95 & 1.13 & 0.87 \\
\hline & Guyana & 0.82 & 1.59 & 0.91 & 0.98 & 0.89 & 1.03 & 0.97 & 0.86 & 0.90 & 1.07 \\
\hline & Honduras & 0.80 & 1.61 & 0.82 & 1.19 & 0.98 & 1.00 & 1.00 & 0.98 & 0.97 & 1.03 \\
\hline & Jamaica & 0.96 & 1.16 & 1.01 & 0.80 & 0.81 & 1.07 & 0.93 & 0.76 & 0.95 & 0.99 \\
\hline & Mexico & 0.64 & 2.48 & 0.80 & 1.16 & 0.93 & 1.02 & 0.98 & 0.91 & 0.79 & 1.23 \\
\hline & Nicaragua & 0.62 & 2.66 & 0.56 & 1.66 & 0.93 & 1.00 & 1.00 & 0.93 & 1.11 & 0.91 \\
\hline & Panama & 0.97 & 1.14 & 0.90 & 1.04 & 0.93 & 0.99 & 1.01 & 0.94 & 1.08 & 0.93 \\
\hline & Paraguay & 0.56 & 3.02 & 0.61 & 1.56 & 0.96 & 1.06 & 0.94 & 0.90 & 0.92 & 1.02 \\
\hline & Peru & 0.57 & 3.03 & 0.67 & 1.54 & 1.03 & 1.02 & 0.98 & 1.01 & 0.86 & 1.14 \\
\hline & Puerto Rico & 1.00 & 1.00 & 1.00 & 1.13 & 1.13 & 1.13 & 0.88 & 1.00 & 1.00 & 0.88 \\
\hline & Suriname & 1.03 & 1.06 & 1.01 & 0.81 & 0.81 & 1.02 & 0.98 & 0.80 & 1.02 & 0.96 \\
\hline & Trinidad and Tobago & 1.00 & 1.02 & 0.92 & 1.17 & 1.07 & 1.04 & 0.96 & 1.03 & 1.09 & 0.89 \\
\hline & Uruguay & 0.74 & 1.82 & 0.88 & 1.05 & 0.93 & 1.06 & 0.94 & 0.87 & 0.84 & 1.12 \\
\hline & Venezuela, RB & 0.62 & 2.60 & 0.91 & 0.93 & 0.85 & 1.11 & 0.90 & 0.76 & 0.68 & 1.32 \\
\hline
\end{tabular}

Table 7

Calculations of productivity changes using the metafrontier Malmquist method for Middle East and North Africa

\begin{tabular}{|c|c|c|c|c|c|c|c|c|c|c|c|}
\hline & & TEC* & $\mathbf{T C}^{*}$ & TEC $^{k}$ & $\mathrm{TC}^{k}$ & GMPI & Cach-Up & TGRC & MMPI & PTCU & FCU \\
\hline \multirow{15}{*}{$\begin{array}{c}\text { Middle } \\
\text { East and } \\
\text { North } \\
\text { Africa }\end{array}$} & Algeria & 0.76 & 1.72 & 0.94 & 1.04 & 0.98 & 1.10 & 0.91 & 0.89 & 0.81 & 1.12 \\
\hline & Bahrain & 0.95 & 1.15 & 1.00 & 1.03 & 1.03 & 1.02 & 0.98 & 1.01 & 0.95 & 1.03 \\
\hline & Egypt, Arab Rep. & 0.83 & 1.45 & 0.80 & 1.26 & 1.01 & 1.02 & 0.98 & 0.99 & 1.04 & 0.94 \\
\hline & Iran, Islamic Rep. & 0.87 & 1.31 & 0.83 & 1.26 & 1.05 & 0.97 & 1.03 & 1.08 & 1.05 & 0.98 \\
\hline & Israel & 1.00 & 1.02 & 1.00 & 1.39 & 1.39 & 1.02 & 0.98 & 1.36 & 1.00 & 0.98 \\
\hline & Jordan & 1.08 & 0.84 & 0.96 & 1.08 & 1.04 & 0.98 & 1.02 & 1.06 & 1.12 & 0.91 \\
\hline & Kuwait & 0.84 & 1.51 & 1.00 & 1.11 & 1.11 & 1.07 & 0.93 & 1.04 & 0.84 & 1.11 \\
\hline & Lebanon & 0.76 & 1.64 & 1.00 & 1.07 & 1.07 & 1.12 & 0.89 & 0.95 & 0.76 & 1.18 \\
\hline & Libya & 0.73 & 1.90 & 0.67 & 1.51 & 1.01 & 1.01 & 0.99 & 1.01 & 1.08 & 0.92 \\
\hline & Morocco & 0.83 & 1.39 & 0.68 & 1.55 & 1.06 & 1.11 & 0.90 & 0.95 & 1.21 & 0.74 \\
\hline & Oman & 0.99 & 1.03 & 1.06 & 1.05 & 1.12 & 1.01 & 0.99 & 1.10 & 0.93 & 1.06 \\
\hline & Qatar & 1.00 & 1.14 & 1.00 & 1.19 & 1.19 & 1.11 & 0.90 & 1.07 & 1.00 & 0.90 \\
\hline & Saudi Arabia & 0.99 & 1.11 & 1.00 & 1.35 & 1.35 & 1.15 & 0.87 & 1.17 & 0.99 & 0.87 \\
\hline & Tunisia & 1.30 & 0.59 & 0.92 & 1.31 & 1.21 & 0.97 & 1.03 & 1.24 & 1.41 & 0.73 \\
\hline & United Arab Emirates & 1.00 & 1.07 & 1.00 & 1.25 & 1.25 & 1.07 & 0.93 & 1.17 & 1.00 & 0.93 \\
\hline
\end{tabular}

Table 8

Calculations of productivity changes using the metafrontier Malmquist method for North America

\begin{tabular}{|c|c|c|c|c|c|c|c|c|c|c|c|}
\hline & & TEC $^{*}$ & TC $^{*}$ & TEC $^{k}$ & $\mathrm{TC}^{k}$ & GMPI & Cach-Up & TGRC & MMPI & PTCU & FCU \\
\hline \multirow[b]{2}{*}{ North America } & Canada & 1.00 & 1.10 & 1.00 & 1.22 & 1.22 & 1.10 & 0.91 & 1.11 & 1.00 & 0.91 \\
\hline & United States & 1.00 & 1.11 & 1.00 & 1.12 & 1.12 & 1.06 & 0.94 & 1.05 & 1.00 & 0.94 \\
\hline
\end{tabular}


Table 9

Calculations of Productivity Changes using the metafrontier Malmquist method for South Asia

\begin{tabular}{llcccccccccc}
\hline & & TEC $^{*}$ & TC $^{*}$ & TEC $^{\boldsymbol{k}}$ & TC $^{\boldsymbol{k}}$ & GMPI $^{\text {Cach-Up }}$ & TGRC & MMPI & PTCU & FCU \\
\hline \multirow{3}{*}{ South Asia } & Bangladesh & 0.69 & 2.10 & 1.00 & 0.98 & 0.98 & 1.26 & 0.80 & 0.78 & 0.69 & 1.16 \\
& India & 0.97 & 1.08 & 1.00 & 2.01 & 2.01 & 1.22 & 0.82 & 1.64 & 0.97 & 0.84 \\
& Pakistan & 0.83 & 1.46 & 1.00 & 1.11 & 1.11 & 1.18 & 0.85 & 0.94 & 0.83 & 1.02 \\
\hline
\end{tabular}

Table 10

Calculations of Productivity Changes using the metafrontier Malmquist method for Sub-Saharan Africa

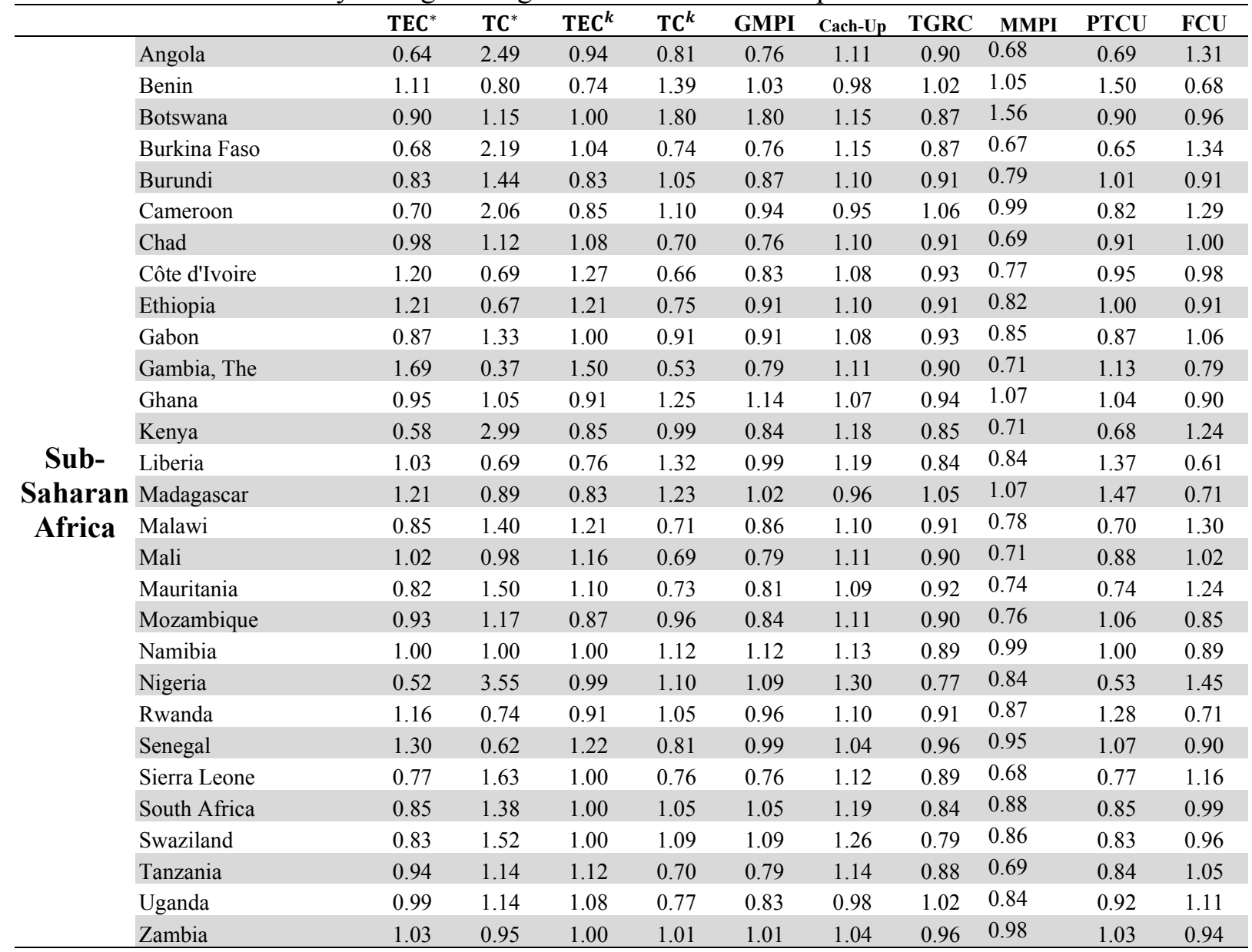

\subsection{Calculating the group and metafrontier Malmquist indices and their elements at the geographical areas level}

Table 11 shows the mean of group Malmquist index and its elements. As it can be seen in the table the group Malmquist index and its elements are calculated for the Iran group with a fixed-scale efficiency for 2007-2014.

\section{Table 11}

Mean value of the metafrontier Malmquist index and its elements at the geographical level

\begin{tabular}{|c|c|c|c|c|c|c|c|c|c|c|}
\hline & TEC * & TC* & TEC $^{k}$ & $\mathrm{TC}^{\mathrm{k}}$ & GMPI & (Cach-Up) & TGRC & MMPI & PTCU & FCU \\
\hline East Asia and Pacific & 0.94 & 1.24 & 0.94 & 1.22 & 1.10 & 1.04 & 0.96 & 1.06 & 1.03 & 0.94 \\
\hline Europe and Central Asia & 0.90 & 1.34 & 0.91 & 1.20 & 1.07 & 1.01 & 0.99 & 1.06 & 0.99 & 1.00 \\
\hline Latin America and Caribbean & 0.81 & 1.87 & 0.84 & 1.19 & 0.96 & 1.05 & 0.96 & 0.91 & 0.96 & 1.01 \\
\hline Middle East and South Africa & 0.93 & 1.26 & 0.93 & 1.23 & 1.12 & 1.05 & 0.96 & 1.07 & 1.01 & 0.96 \\
\hline North America & 1.00 & 1.11 & 1.00 & 1.17 & 1.17 & 1.08 & 0.93 & 1.08 & 1.00 & 0.93 \\
\hline SOUTH ASIA & 0.83 & 1.55 & 1.00 & 1.37 & 1.37 & 1.22 & 0.82 & 1.12 & 0.83 & 1.01 \\
\hline Sub-Saharan Africa & 0.95 & 1.33 & 1.02 & 0.96 & 0.94 & 1.10 & 0.91 & 0.86 & 0.95 & 1.01 \\
\hline Mean & 0.91 & 1.38 & 0.95 & 1.19 & 1.10 & 1.08 & 0.93 & 1.02 & 0.97 & 0.98 \\
\hline
\end{tabular}


According to Table 11, the values of technical efficiency change, technology change, and pure technical backwardness compensation, and backwardness compensation boundary have been calculated. In addition to these values, metafrontier technical efficiency, metafrontier technical change, and the metafrontier Malmquist index are calculated in these periods. By reviewing the changes of technical efficiency, it can be seen that the North America region had better performance and other areas, especially Latin America and The Caribbean and South Asia, have experienced a decline in technical efficiency. In MENA region and $\left(\right.$ TEC $\left.^{k}=0.93\right)$, the technical efficiency has decreased (TCE $*=0.93$ ) compared to the whole world. This is despite the fact that technical efficiency has been totally decreased (TEC* $=0.91)$. A review of technological change indicates that in all areas technology growth is observed to improve the entrepreneurship ecosystem and the growth global average is 0.38 ( $\left.\mathrm{TC}^{*}=1.38\right)$. In the study period, Latin America and The Caribbean have experienced the most growth. Also, by examining the Group Malmquist Productivity index (GMPI) and metafrontier Malmquist Productivity index (MMPI), it can be seen that this index has improved over the studied period, but as noted in the previous paragraph, this growth has been driven by technological growth, not the growth of technical efficiency. East Asia and Pacific, Middle East and North America are seeking a way to reduce the technology gap in the area of entrepreneurship ecosystems, and given the issue that the values of backwardness compensation boundary is greater than 1 in Latin America and The Caribbean, South Asia and Sub-Saharan Africa, these areas have potential for developing technological standards.

\subsection{Calculation of the technology gap ratio}

Table 12 shows the index of technology gap ratio for different regions.

\section{Table 12}

Technology gap ratio at the geographical level

\begin{tabular}{lcc} 
& $T G R_{t}^{k}\left(x_{t}, y_{t}\right)$ & $T G R_{t+1}^{k}\left(x_{t+1}, y_{t+1}\right)$ \\
\hline East Asia and Pacific & 0.92 & 0.94 \\
Europe and Central Asia & 0.96 & 0.95 \\
Latin America and The Caribbean & 0.85 & 0.81 \\
Middle East and North Africa & 0.89 & 0.89 \\
North America & 1.00 & 1.00 \\
South Asia & 0.55 & 0.47 \\
Sub-Saharan Africa & 0.55 & 0.51 \\
\hline
\end{tabular}

South Asia and Sub-Saharan Africa have the widest gap with the metafrontier and North America has the smallest gap. In other words, North America can be said to be the best region for the entrepreneurship ecosystem, which also formed an efficient metafrontier in this region. The next area, positioned at a short distance from metafrontier, is Europe and Central Asia.

\section{Conclusions}

In developed countries, evaluating the entrepreneurship ecosystem is necessary for being progressive, and in developing countries this evaluation is essential for estimating their position and accelerating the rate of progress in the area of entrepreneurship. Previous analyses examined indices individually and focused only on the output. The DEA-based metafrontier Malmquist approach has been selected for evaluation because: the change pattern of each country should be found (DEA); analyses should be done dynamically and the effects of technical and technology changes must be identified in the whole changes (Malmquist); and region and level of countries should be considered in analysis (metafrontier). Thus this study is aimed to evaluate the entrepreneurship ecosystem of the countries according to their level and based on the Global Entrepreneurship index (GEI) with the metafrontier Malmquist method. By examining the value of Group Malmquist Productivity Index (GMPI) and metafrontier Malmquist Productivity Index (MMPI), it can be seen that the index has improved over the years of study, but a deeper analysis better illustrates the reason for this growth. The results indicate that in 2017, compared to 2016, there will be technological growth in all areas of the economy to improve the entrepreneurship ecosystem, which means that the entrepreneurship ecosystem is generally growing. But in the whole world, the technical efficiency of 2017 has been decreased compared to 2016. In fact, the growth of 
observed performance in the world is not due to the better use of resources, but the global growth of the whole world. Meanwhile, the North America region has had the best technical performance in the development of entrepreneurship ecosystem, and other areas, especially Latin America and The Caribbean and South Asia, have experienced a decline in technical efficiency. It was also found that East Asia and Pacific, Middle East and North Africa and North America had a technology gap in the area of entrepreneurship ecosystems, and Latin America and The Caribbean, South Asia and Sub-Saharan Africa regions had the potential to develop technological standards. North America has the minimum gap in terms of technology gap. In other words, North America can be said to be the best region for the entrepreneurial ecosystem, which is also the efficient metafrontier region. The next area, positioned at a short distance from the metafrontier, is Europe and Central Asia. South Asia and Sub-Saharan Africa have the widest gap with metafrontier. By analyzing metafrontier, simple analysis of the entrepreneurship ecosystem performance was replaced with the deep analysis and a more comprehensive view was achieved in this area.

\section{References}

Ács, Z. J., \& Szerb, L. (2012). Global entrepreneurship and development index 2012. Edward Elgar Publishing.

Ács, Z. J., Autio, E., \& Szerb, L. (2014). National systems of entrepreneurship: Measurement issues and policy implications. Research Policy, 43(3), 476-494.

Adams, R. B., Licht, A. N., \& Sagiv, L. (2011). Shareholders and stakeholders: How do directors decide?. Strategic Management Journal, 32(12), 1331-1355.

Amolo, J., \& Migiro, S. O. (2015). An entrepreneurial flair development: the role of an ecosystem. Problems and Perspectives in Management, 13(2), 494-505

Aoyama, Y. (2009). Entrepreneurship and regional culture: The case of Hamamatsu and Kyoto, Japan. Regional Studies, 43(3), 495-512.

Baumol, W. J. (1996). Entrepreneurship: Productive, unproductive, and destructive. Journal of Business Venturing, 11(1), 3-22.

Bahrami, H., \& Evans, S. (1995). Flexible re-cycling and high-technology entrepreneurship. California Management Review, 37(3), 62-89.

Caves, D. W., Christensen, L. R., \& Diewert, W. E. (1982a). The economic theory of index numbers and the measurement of input, output, and productivity. Econometrica: Journal of the Econometric Society, 13931414.

Caves, D. W., Christensen, L. R., \& Diewert, W. E. (1982b). Multilateral comparisons of output, input, and productivity using superlative index numbers. The economic journal, 92(365), 73-86.

Chung, Y., \& Heshmati, A. (2015). Measurement of environmentally sensitive productivity growth in Korean industries. Journal of Cleaner Production, 104, 380-391.

Cohen, B. (2006). Sustainable valley entrepreneurial ecosystems. Business Strategy and the Environment, 15(1), $1-14$.

Davari, A., Sefidbarfi, L. \& Baghersadr, V. (2017). The factors of the Iranian entrepreneurship ecosystem based on the Eisenberg model. Entrepreneurship Development Quarterly, 10(1), 120-100. (In Persian)

Drakopoulou Dodd, S., \& Anderson, A. R. (2007). Mumpsimus and the mything of the individualistic entrepreneur. International Small Business Journal, 25(4), 341-360.

Dubini, P. (1989). The influence of motivations and environment on business start-ups: Some hints for public policies. Journal of Business Venturing, 4(1), 11-26.

Entezari, Y. (2015). Building knowledge-based entrepreneurship ecosystems: Case of Iran. Procedia-social and Behavioral Sciences, 195, 1206-1215.

Farrell, M. J. (1957). The measurement of productive efficiency. Journal of the Royal Statistical Society. Series A (General), 120(3), 253-290.

Feldman, M. P. (2001). The entrepreneurial event revisited: firm formation in a regional context. Industrial and corporate change, 10(4), 861-891.

Feldman, M., Francis, J., \& Bercovitz, J. (2005). Creating a cluster while building a firm: Entrepreneurs and the formation of industrial clusters. Regional studies, 39(1), 129-141.

Freeman, J. H., \& Audia, P. G. (2006). Community ecology and the sociology of organizations. The Annual Review of Sociology., 32, 145-169.

Fritsch, M. (2013). New business formation and regional development: A survey and assessment of the evidence. Foundations and Trends ${ }^{\circledR}$ in Entrepreneurship, 9(3), 249-364. 
Gnyawali, D. R., \& Fogel, D. S. (1994). Environments for entrepreneurship development: key dimensions and research implications. Entrepreneurship Theory and Practice, 18(4), 43-62.

Henrekson, M., \& Sanandaji, T. (2014). Small business activity does not measure entrepreneurship. Proceedings of the National Academy of Sciences, 111(5), 1760-1765.

Iansiti, M., \& Levien, R. (2004). The keystone advantage. Harvard Business School Press, Boston.

Isenberg, D. (2011). The entrepreneurship ecosystem strategy as a new paradigm for economic policy: Principles for cultivating entrepreneurship. Presentation at the Institute of International and European Affairs.

Johannisson, B. (2011). Towards a practice theory of entrepreneuring. Small Business Economics, 36(2), 135150.

Kumbhakar, S. C., \& Wang, H. J. (2005). Estimation of growth convergence using a stochastic production frontier approach. Economics Letters, 88(3), 300-305.

Lin, E. Y. Y., Chen, P. Y., \& Chen, C. C. (2013). Measuring green productivity of country: A generlized metafrontier Malmquist productivity index approach. Energy, 55, 340-353.

Lu, Y. H., Chen, K. H., \& Wu, C. C. (2015). Cross-country analysis of efficiency and productivity in the biotech industry: an application of the generalized metafrontier Malmquist productivity index. Agricultural Economics-Czech, 61, 116-134.

Mack, E., \& Mayer, H. (2016). The evolutionary dynamics of entrepreneurial ecosystems. Urban Studies, 53(10), 2118-2133.

Mason, C., \& Brown, R. (2014). Entrepreneurial ecosystems and growth oriented entrepreneurship. Final Report to OECD, Paris, 30(1), 77-102.

Molinos-Senante, M., Hernández-Sancho, F., \& Sala-Garrido, R. (2015). Comparing the dynamic performance of wastewater treatment systems: A metafrontier Malmquist productivity index approach. Journal of Environmental Management, 161, 309-316.

Moore, J. F. (1993). Predators and prey: a new ecology of competition. Harvard Business Review, 71(3), 75-86.

Moore, J. F. (1996). The death of competition: leadership and strategy in the age of business ecosystems (p. 297). New York: HarperBusiness.

O'Donnell, C. L. (2008). Defining, conceptualizing, and measuring fidelity of implementation and its relationship to outcomes in K-12 curriculum intervention research. Review of Educational Research, 78(1), 33-84.

Patton, D., \& Kenney, M. (2005). The spatial configuration of the entrepreneurial support network for the semiconductor industry. $R \& D$ Management, 35(1), 1-16.

Pennings, J. M. (1982). Organizational birth frequencies: An empirical investigation. Administrative Science Quarterly, 27(1), 120-144.

Shane, S., \& Venkataraman, S. (2000). The promise of entrepreneurship as a field of research. Academy of management review, 25(1), 217-226.

Simrie, M., Herrington, D., Kew, J., \& Turton, N. (2011). Global Entrepreneurship Monitor 2011. South African Report, website: http://www. gemconsortium. org/docs/2313/gem-south-africa-2011-report (accessed September 2012).

Spigel, B. (2017). The relational organization of entrepreneurial ecosystems. Entrepreneurship Theory and Practice, 41(1), 49-72.

Sternberg, R. (2007). Entrepreneurship, proximity and regional innovation systems. Tijdschrift voor economische en sociale geografie, 98(5), 652-666.

Van de Ven, H. (1993). The development of an infrastructure for entrepreneurship. Journal of Business Venturing, 8(3), 211-230.

Walter, S. G., \& Dohse, D. (2012). Why mode and regional context matter for entrepreneurship education. Entrepreneurship \& Regional Development, 24(9-10), 807-835.

Welter, F. (2011). Contextualizing entrepreneurship - conceptual challenges and ways forward. Entrepreneurship Theory and Practice, 35(1), 165-184.

Wolff, E. N. (2013). Productivity convergence: theory and evidence. Cambridge University Press.

Zahra, S. A., Wright, M., \& Abdelgawad, S. G. (2014). Contextualization and the advancement of entrepreneurship research. International Small Business Journal, 32(5), 479-500.

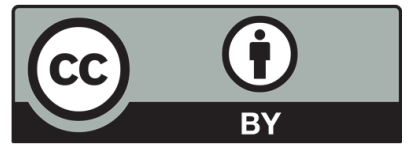

(C) 2018 by the authors; licensee Growing Science, Canada. This is an open access article distributed under the terms and conditions of the Creative Commons Attribution (CC-BY) license (http://creativecommons.org/licenses/by/4.0/). 